УДК 349.2

DOI https://doi.org/10.32844/2618-1258.2019.3-2.6

ЧЕРНЕГА Р.T.

\title{
СПІВВІДНОШЕННЯ РЕАЛІЗАЦІЇ ТА ЗАХИСТУ ПРАВА НА ОХОРОНУ ПРАЦІ ІЗ ЗАБЕЗПЕЧЕННЯМ ОХОРОНИ ПРАЦІ
}

3'ясовано, що важливим є виокремлення формування загальносоціальних гарантій, що є початковою стадією запровадження правового забезпечення. Цілком логічним видається розмежування охорони та захисту прав, оскільки з боку держави необхідним є забезпечення гарантій реалізації прав шляхом попередження можливих правопорушень та можливості відновлення прав у разі протиправної поведінки. При цьому такі гарантії є різними за своєю правовою природою. Наголошено, що охорона праці може розглядатись як комплексне явище й включатиме різні наукові засоби та способи для врегулювання. Охорона праці не може відбуватись без правового регулювання, що є їі базисом. Розглядаючи в правовому аспекті охорону праці, iї слід розуміти як інститут трудового права. Відповідно до даних тверджень ми можемо надати наступні декілька визначень охорони праці. Під час визначення правового забезпечення очевидним є наявність як самої дії уповноважених суб' єктів, так і результату таких дій у формі встановлених гарантій. Визначено, що правовим забезпеченням $є$ цілеспрямована, системна діяльність держави та іiї вповноважених державних органів щодо встановлення правових норм, які регулюють суспільні відносини, а також діяльність з контролю щодо дотриманням встановлених норм, притягнення до юридичної відповідальності за допомогою комплексу юридичних засобів, забезпечених силою державного примусу, у разі недотримання встановлених норм. Зроблено висновок, що правове забезпечення охорони праці це цілеспрямована, системна діяльність держави та її вповноважених державних органів щодо встановлення правових норм, які регулюють трудові правовідносини та пов'язані з ними відносини, а також діяльність 3 контролю щодо дотримання правових норм, притягнення до юридичної відповідальності за допомогою комплексу соціальних, фізичних та юридичних засобів, забезпечених силою державного примусу, з метою регламентації поведінки роботодавця щодо надання гарантій забезпечення прав працівника на життя, здоров'я та безпечні умови праці.

Ключові слова: трудове право, принципи, охорона праці, правове регулювання.

It has been found that it is important to distinguish the formation of social guarantees, which is the initial stage of introducing legal support, and to set the framework for appropriate security. It is quite logical to distinguish between the protection and protection of rights, since on the part of the state it is necessary to provide guarantees for the realization of rights by preventing possible offenses and the possibility of restoring rights in the case of unlawful behavior. However, these warranties are obviously different in nature. It is emphasized that occupational safety and health can be considered as a complex phenomenon and will include various scientific means and methods of regulation. Labor protection cannot take place without the legal regulation that underlies it. Considering the legal aspect of labor protection, it should be understood as an institution of labor law. According to these statements, we can provide some of the following definitions of occupational safety. When defining a legal security, it is obvious that both the action of the authorized entities and the result of such actions in the form of guarantees are evident. It is determined that legal support is purposeful, systematic activity of the state and its authorized state bodies, in establishing legal norms that regulate public relations, as well as activities in monitoring compliance with the established norms, bringing to

(C) ЧЕРНЕГА Р.Т. - кандидат юридичних наук, голова (Державна служба України з питань 
legal responsibility by means of a complex of legal means secured by the force of state. coercion, in case of non-compliance with established standards. It is concluded that the legal protection of labor protection is a purposeful, systematic activity of the state and its authorized state bodies, in establishing legal rules governing labor relations and related relations, as well as activities in monitoring compliance with legal norms, bringing to legal liability through a complex of social, physical and legal means, secured by the force of state coercion to regulate the behavior of the employer in providing guarantees for the protection of to life, health and safe working conditions.

Key words: labor law, principles, labor protection, legal regulation.

Вступ. Охорона праці пов'язана із розумінням прав і свобод людини, громадянського суспільства, верховенства права та соціальної справедливості. Дослідження поняття охорони праці, iï сутності та ознак забезпечить формування спільного категоріального апарату, дозволить об'єднати теоретичні дослідження із різних наукових напрямів, що вплине й на загальний розвиток науки та правового регулювання. Дослідження ознак та сутності дозволить конкретизувати та виділити межі охорони праці, визначити, які заходи необхідно системно реалізувати для збереження iii ефективності. Саме тому дослідження поняття охорони праці, її сутності й ознак $є$ актуальним

Стан дослідження. На науково-теоретичному рівні питання охорони праці розглядається в правовому, економічному та соціальних аспектах. Комплексним дослідженням охорони праці займались такі науковці, як С.Я. Вавженчук, В.С. Венедіктов, Г.Г. Гогіташвілі, Р.В. Івах, Ю.Ю. Івчук, П.О. Ізуїта, М.І. Іншин, М. Яремко. Окремими питаннями розвитку та регулювання охорони праці займались такі науковці, як К.М. Андрющенко, О.П. Буднік, Н.В. Дараганова, М.О. Дей, Л.М. Корольчук Ю.А. Селезньова. Проте й досі відсутня єдність серед науковців щодо розуміння охорони праці, її сутності, ознак, дослідження яких є особливо актуальним сьогодні.

Результати дослідження. У правовому розумінні охорона праці належить до сфери регулювання трудового права, що спричиняє наступні питання щодо розуміння охорони праці.

Ряд вчених розуміє охорону праці як основну мету та функцію усього трудового права. Так, У. Бек зазначає, що й поняття «охорона праці» уособлює в собі всі норми трудового права, $€$ всією його сутністю [1, с. 228]. Справді, немає жодного інституту трудового права, який би в широкому його розумінні не був би спрямований на охорону праці та збереження життя і здоров'я працівників [1, с. 228]. Ми погоджуємось із загальним розумінням. Разом з тим вважаємо, що це положення не до кінця розкриває усю сутність правового підходу до розуміння охорони праці, й його можна розглянути й відповідно до інших підходів, які, однак, не будуть йому суперечити.

Так, відповідно до іншого підходу охорона праці розглядається як принцип трудового права. Ю.П. Дмитренко до основних принципів трудового права відніс і принцип безпеки праці, тобто створення безпечних умов праці на виробництві, дотримання правил техніки безпеки праці тощо [2, с. 103]. Науковці-правовики із ЛНУ ім. І. Франка вказують, що правовий принцип трудового права охорони праці відображає зміст усіх норм трудового права, які за своєю сутністю спрямовані на охорону здоров'я та працездатності працівників [3, с. 392]. У цьому значенні охорона праці є галузевим правовим принципом, оскільки відображає його соціальну спрямованість на захист трудових прав працівників. Розглядаючи цей підхід та попередній, ми не можемо знайти суттєвої різниці [3, с. 392]. Оскільки основним твердженням обох підходів є спрямованість трудового права на охорону та захист природних прав працюючого. Знову ж таки, погоджуючись із загальною ідеєю, хочемо зазначити, що серед усіх норм трудового права є особливі, які безпосередньо регулюють охорону праці.

Це твердження є однією із тез, що обгрунтовує третій підхід, згідно з яким охорона праці $\epsilon$ інститутом трудового права. Так, П.О. Ізуїта зазначає, що охорона праці як інститут трудового права представлена сукупністю правових норм, що регулюють відносини по забезпеченню безпечних та здорових умов праці, а також спеціальних умов праці жінок, неповнолітніх, інвалідів та осіб, які працюють на роботах зі шкідливими, важкими і небезпечними умовами праці [4, с. 13]. Таке визначення є вдалим щодо встановлення основних суб'єктів охорони та надання охороні праці певної галузевої приналежності. В той же час, аналізуючи визначення, ми не можемо зрозуміти мету правового регулювання охорони праці.

Н.В. Дараганова вказує, що охорона праці є одним із інститутів галузі трудового права, який можна визначити як сукупність правових норм, що регулюють відносини щодо забезпечення безпечних та здорових умов праці, спрямованих на збереження життя і здоров'я працівників 
[5, с. 9]. На противагу попередньому визначенню, автор акцентує увагу саме на меті охорони праці - збереження життя і здоров'я працівника. Отже, ми погоджуємось із розумінням охорони праці як інституту трудового права та визначенням мети правового регулювання охорони праці.

Отже, розглядаючи питання розуміння поняття охорони праці, ми дійшли декількох висновків. Охорона праці може розглядатись як комплексне явище й включатиме різні наукові засоби та способи для врегулювання. Охорона праці не може відбуватись без правового регулювання, що $є$ іiї базисом. Розглядаючи в правовому аспекті охорону праці, іï слід розуміти як інститут трудового права. Відповідно до таких тверджень ми можемо надати декілька визначень охорони праці.

Розглядаючи охорону праці у вузькому розумінні, як інститут трудового права, ми дійшли висновку, що це поняття варто визначити в об'єктивному та суб'єктивному значенні.

Охорона праці в об'єктивному значенні - це система правових норм, що регулюють правовідносини між роботодавцем та працівником щодо безпеки праці, та діяльність вповноважених органів, які здійснюють контроль та нагляд за діяльністю роботодавця з метою регуляції його поведінки щодо забезпечення прав працівника на життя, здоров'я та безпечні умови праці.

Охорона праці в суб' єктивному значенні - це система прав працівника, забезпечених державою та ії вповноваженими органами щодо здійснення усіх можливих дій задля забезпечення сприятливих умов праці та збереження життя і здоров'я, які здійснюються відповідно до правових норм.

Розглядаючи охорону праці комплексно, ми дійшли висновку, що це цілеспрямована, системна діяльність держави та ії вповноважених державних органів, яка здійснюється шляхом регулювання трудових правовідносин та пов'язаних з ними відносин, контролю щодо дотримання правових норм, притягнення до юридичної відповідальності за допомогою комплексу соціальних та фізичних заходів, забезпечених силою державного примусу, з метою регламентації поведінки роботодавця щодо забезпечення прав працівника на життя, здоров'я та безпечні умови праці.

O.I. Наливайко сприймає феномен «забезпечення» прав людини в ракурсі діяльності органів держави і місцевого самоврядування, громадських об'єднань і громадян із створення умов (гарантій) для правомірної та неухильної їх реалізації і захисту [6, с. 22]. Разом з тим відповідна дефініція є лише частиною попередньої та не включає самі гарантії як складник забезпечення, виділяючи лише діяльність владних органів щодо їх створення, реалізації та захисту. Враховуючи відсутність частини обов'язкових, на нашу думку, складників, вважаємо останнє визначення менш вдалим.

B.О. Демиденко під правовим забезпеченням прав і свобод людини розуміє передовсім сприяння їх реалізації, охороні та захисту [7, с. 13]. Таким чином, автор також не вбачає у змісті правового забезпечення самих гарантій. Водночас під «сприянням» в цьому контексті розуміється діяльність уповноважених органів щодо встановлення таких гарантій, що опосередковано дає можливість для розуміння їх наявності.

На думку В.В. Піцикевича, правове забезпечення - правомірна поведінка осіб щодо створення умов, за яких: а) суб'єкти права матимуть змогу належним чином реалізувати свої права, свободи та інтереси; б) діє система гарантій для набуття, реалізації, охорони та захисту прав, свобод та інтересів осіб [8, с. 38]. Таке визначення є досить цікавим з наукової точки зору, оскільки передбачає діяльність осіб щодо забезпечення можливості реалізації прав, а також впровадження дії системи гарантій відповідної реалізації. Отже, розглядається діяльність осіб щодо забезпечення належних умов для реалізації суб'єктами своїх прав.

Я.В. Лазур вбачає правове забезпечення як здійснюване державою за допомогою правових норм, приписів і сукупності засобів упорядкування суспільних відносин щодо їх юридичного закріплення, реалізації, охорони, захисту і відновлення [9, с. 392]. Подібне визначення надає і М.В. Фролков, на думку якого, правове забезпечення - це здійснюване державою за допомогою правових норм, приписів і сукупності засобів упорядкування суспільних відносин, їх юридичне закріплення, охорона, реалізація і розвиток [10, с. 549]. М.В. Цвік також визначає правове забезпечення як цілеспрямований вплив на поведінку людей і суспільні відносини за допомогою правових (юридичних) засобів [11, с. 327]. Отже, авторами підтримується діяльнісний підхід, який передбачає визначений порядок дій держави, отже, можемо спостерігати, що такий підхід до визначення правового забезпечення $є$ поширеним серед вчених. Разом з тим не можемо погодитись із цими визначеннями, оскільки розглядається упорядкування суспільних відносин з метою їх закріплення, реалізації, захисту та відновлення. Однак, на нашу думку, правове забезпечення 
більш доцільно розглядати через призму надання прав та гарантій їх реалізації. Надане право не $\epsilon$ активною дією суб'єкта, позаяк суспільні відносини передбачають окремі дії суб'єктів, між якими такі правовідносини виникли. Правове забезпечення, на нашу думку, не створює правовідносини між суб'єктами, а лише встановлює умови для вступу суб'єктів у них.

К.Г. Волинка зводить зміст поняття «правового забезпечення» прав і свобод людини до ïx поваги, дотримання, визнання та гарантій $[12$, с. 5]. Суттєвим недоліком такого визначення $є$ те, що їх автор не пов'язує можливість такого забезпечення з діяльністю уповноважених органів щодо встановлення відповідних гарантій.

Обмеженим за змістом є поняття правового забезпечення, запропоноване А.Є. Олейником. У ньому перевага віддається таким його складовим частинам, як створення сприятливих умов для реалізації громадянами своїх прав, запобігання їх порушенню, відновлення порушених прав громадян [13, с. 16]. Автором не розкрито питання методів забезпечення відповідних умов, до яких насамперед належить діяльність уповноважених суб'єктів щодо унормування гарантій реалізації прав і свобод осіб шляхом встановлення відповідних правових приписів.

3 погляду А.Ю. Олійника, правове забезпечення - це вплив на права і свободи громадян за допомогою певних юридичних засобів, насамперед норм права $[14$, с. 160]. Вченим також не звернута увага на необхідність участі держави в правовому забезпеченні. Виділення норм права як інструменту впливу не може розглядатись як діяльність держави, оскільки використання норм здійснюється не лише з боку держави, а й іншими суб'єктами. Монопольною ж можливістю встановлення норм права, за винятком локальних актів, володіє держава. Окрім цього, наведена дефініція не розкриває інших важливих ознак правового забезпечення, зокрема такої, як мета відповідного впливу.

У своїх висновках О.М. Дручек зазначає, що причиною помилок науковців у процесі формування змісту поняття правового забезпечення слугує упущення факту двоякості терміну «забезпечення»: це і сукупність гарантій (у контексті нашого дослідження, зокрема гарантій реалізації і охорони прав), і водночас це процес, діяльність (органів державної влади щодо створення умов, необхідних для реалізації прав). Йдеться про статичний і динамічний аспект поняття «правового забезпечення». Тобто можливість присутності винятково одного компоненту виключається. Разом із тим вчений вважає, що мають рацію ті дослідники, які розкривають поняття «забезпечення» через конструкцію «створення умов», або «впорядкування», оскільки означені дії самі по собі є процесом і станом і передбачають різні форми діяльності суб'єктів владних повноважень [15, с. 124]. Цілком погоджуємось із вказаною позицією, оскільки багатоаспектність поняття викликає необхідність включення до його складу ряду важливих ознак, які найбільш повно розкривають окрему дефініцію. Під час визначення правового забезпечення очевидним $\epsilon$ наявність як самої дії уповноважених суб'єктів, так і результату таких дій у формі встановлених гарантій. Водночас погоджуємось із позицією щодо можливості визначення дій уповноважених суб' єктів через «створення умов» чи «упорядкування» та відмітимо, що відповідні формулювання включають в себе створення окремих гарантій. Тоді як під формулюванням впливу встановлення гарантій як початкова стадія не вбачається.

В такому контексті цікавим вважаємо розуміння «забезпечення» Ю.Ф. Кравченко щодо включення до цього поняття трьох елементів, а саме: сприяння реалізації прав і свобод людини (шляхом позитивного впливу на формування їх загальносоціальних гарантій); охорону прав i свобод людини (шляхом упровадження заходів, зокрема юридичних, для попередження, профілактики порушень прав і свобод людини); захист прав і свобод людини (відновлення порушеного правового стану, притягнення порушників до юридичної відповідальності) [16, с. 130]. Підтримуємо такий підхід, оскільки автором досить повно визначено складники змісту цього поняття. Важливим є виокремлення формування загальносоціальних гарантій, що є початковою стадією запровадження правового забезпечення та задає рамки відповідного забезпечення. Цілком логічним видається розмежування охорони та захисту прав, оскільки з боку держави необхідним $\epsilon$ забезпечення гарантій реалізації прав шляхом попередження можливих правопорушень та можливості відновлення прав у разі протиправної поведінки. При цьому такі гарантії $\epsilon$, очевидно, різними за своєю правовою природою.

О.С. Костюченко, характеризуючи ключові ознаки правового забезпечення, доходить висновку, що правове забезпечення - це безперервна діяльність суб' єктів права зі створення правових умов в межах їхньої компетенції усіма правовими засобами щодо закріплення, реалізації, гарантування, охорони та захисту прав і свобод осіб та їхніх груп $[17$, с. 15$]$. В такому разі можемо констатувати досить вдале поєднання змістових ознак правового забезпечення, а саме дій 
уповноважених суб'єктів, наявності об'єкту забезпечення, а саме прав і свобод осіб, а також наявності інструментарію - правових засобів, які доступні уповноваженим суб’єктам в межах їх компетенції.

Отже, правовим забезпеченням є цілеспрямована, системна діяльність держави та ії вповноважених державних органів щодо встановлення правових норм, які регулюють суспільні відносини, а також діяльність 3 контролю щодо дотримання встановлених норм, притягнення до юридичної відповідальності за допомогою комплексу юридичних засобів, забезпечених силою державного примусу, у разі недотримання встановлених норм.

У той же час В.Й. Пашинський, висвітлюючи адміністративно-правове забезпечення оборони держави, пропонує розуміти його як регламентовану адміністративно-правовими нормами системну діяльність суб'єктів забезпечення оборони, насамперед суб'єктів публічного управління, щодо адміністративно-правового регулювання, реалізації, охорони та захисту суспільних відносин у сфері оборони, гарантування прав і законних інтересів усіх суб'єктів правовідносин, спрямовану на створення необхідних умов для оборони держави в разі збройної агресії [18, с. 254]. Незважаючи на те, що визначення передбачає наявність необхідності в нормах права, вважаємо, що автором досить вузько проаналізовано поняття правового забезпечення. Зокрема, згадані норми права лише встановлюють межі діяльності органів, які, на думку автора, покликані забезпечити належні умови для реалізації прав суб'єктами правовідносин. Вважаємо, що унормованими повинні бути і самі правовідносини. Тобто норми, що встановлюють правила поведінки осіб, за своєю природою $\epsilon$ окремим видом гарантій, які дозволяють суб'єктам діяти у встановлених межах та очікувати від інших суб’єктів правовідносин діяльності у відповідних встановлених межах.

Висновки. Враховуючи визначені в нашому дослідженні ознаки охорони праці та наведені вище висновки щодо співвідношення реалізації та захисту права на охорону праці, можемо зазначати, що правове забезпечення охорони праці це цілеспрямована, системна діяльність держави та ії вповноважених державних органів щодо встановлення правових норм, які регулюють трудові правовідносини та пов'язані з ними відносини, а також діяльність 3 контролю щодо дотримання правових норм, притягнення до юридичної відповідальності за допомогою комплексу соціальних, фізичних та юридичних засобів, забезпечених силою державного примусу з метою регламентації поведінки роботодавця щодо надання гарантій забезпечення прав працівника на життя, здоров’я та безпечні умови праці.

\section{Список використаних джерел:}

1. Бек У.П. Багатоаспектність поняття охорона праці. Вісник Львівського університету. Серія юридична. 2013. №57. С. 228-234.

2. Дмитренко Ю.П. Трудове право України. Київ : Юрінком Інтер, 2009. 624 с. 2006. $544 \mathrm{c}$.

3. Буряк В.Я. Трудове право України: Академічний курс. Київ : Видавничий Дім «Ін Юре»,

4. Ізуїта П.О. Правове регулювання охорони праці в умовах ринкової економіки : автореф. дис. на здобуття наук. ступеня канд. юр. наук : спец. 12.00.05 «Трудове право; право соціального забезпечення» / Відкритий міжнародний університет розвитку людини «Україна». Х., 2008. 18 с.

5. Дараганова Н.В. Поняття охорони праці: адміністративний аспект. Юридична наука. 2014. №6. С. 7-12.

6. Наливайко О.І. Правовий захист людини як предмет дослідження загальної теорії права II Держава і право. Збірник наукових праць. Юридичні і політичні науки. Вип. 12. К., 2001.

7. Демиденко В.О. Утвердження і забезпечення конституційних прав та свобод людини і громадянина в діяльності міліції : автореф. дис. на здобуття наук. ступ. канд. юрид. наук : спец. 12.00 .02 «Конституційне право». Київ, 2002. 16 с.

8. Піцикевич В. Поняття адміністративно-правового забезпечення ліцензованої діяльності у сфері паливно-енергетичного комплексу України. Юридична Украӥна. 2015. № 4-5. С. 37-40.

9. Лазур Я.В. Поняття, сутність та елементи адміністративно-правового механізму забезпечення прав і свобод громадян у державному управлінні. Форум права. 2009. № 3. С. 392-398.

10. Фролков М.В. Поняття та особливості адміністративно-правового забезпечення захисту прав споживачів. Актуальні проблеми права: теорія і практика. 2013. № 26. С. 547-555.

11. Загальна теорія держави і права : підручник. за ред. М.В. Цвіка, О.В. Петришина. Харків : Право, 2002. 432 с

12. Волинка К.Г. Механізм забезпечення прав і свобод особи: питання теорії і практики : авто- реф. дис. канд. юрид. наук : 12.00.01. Київ, 2000. 16 с. 
13. Олейник А.Е. Совершенствование деятельности милиции по обеспечению конституционных прав неприкосновенности личности, жилища советских граждан и охраны их личной жизни : автореф. дис. канд. юрид. наук. Київ, 1986. 24 с.

14. Олійник А.Ю. Теорія держави і права : навч. посіб. А.Ю. Олійник, С.Д. Гусарєв, О.Л. Слюсаренко. Київ : Юрінком Інтер, 2001. 176 с.

15. Дручек О.М. Поняття адміністративно-правового забезпечення прав, свобод та інтересів дитини органами внутрішніх справ України. Форум права. 2013. № 2.

16. Кравченко Ю.Ф. Свобода як принцип демократичної правової держави : монографія . Ю.Ф. Кравченко. Харків : Вид-во Нац. унту внутр. справ, 2003. 405 с.

17. Костюченко О.Є. Визначення поняття «правове забезпечення». Науковий вісник Національного університету державної податкової служби України. 2015, № 1 (68). С. 11-16.

18. Пашинський В.Й. Адміністративно-правове забезпечення оборони України. Порівняльно-аналітичне право. 2017, № 6. С. 252-255. 